\title{
CRITICAL ASPECTS IN BAIA MARE BASIN (THE SOUTH-WESTERN SECTOR)
}

\section{AURELIA-DANIELA LAZĂR¹, GABRIELA-ALINA MUREŞAN²}

\begin{abstract}
Critical Aspects in Baia Mare Basin (the South-Western Sector). A critical region is a territorial system that has one or more negative elements or interrelations, that can radically deteriorate its state. Sometimes, a territorial unit cannot be defined as critical in its entirety, but contains several critical aspects, generated by instability factors which lead to natural and/or man-made risk phenomena. This paper is focused on the south-western part of the Baia Mare Basin. Several critical aspects have been identified in this area, either induced by natural causes (landslides, ravinement) or by the society (industrial restructuring, demographic aging).
\end{abstract}

Keywords: critical region, landslides, ravinement, vulnerability, demographic aging, Baia Mare Basin.

\section{INTRODUCTION}

The notion of critical region is used to characterize those territorial systems which have one or more negative elements and interrelations, that are considered geographical risks, or are on the outset of a crisis or going through a period of crisis. For this reason, said region can radically deteriorate its state, which makes it a spatial entity with a high risk content, being categorized as a critical region (Boțan, 2005). The concepts of „critical region” and „risk (hazard)” are tightly connected. A region becomes critical when a critical point is reached in its balance due to different natural and man-made disturbing factors. If their action continues and increases and if the territorial system capacity for self-adjustment is exceeded, disfunctions emerge, and the region may destabilize, and lose its dynamic balance and internal structure. The critical region is therefore a unit under threat,

\footnotetext{
${ }^{1}$ Babeş-Bolyai University, Faculty of Geography, 400006, Cluj-Napoca, Romania e-mail: aurelia_auu93@yahoo.com

2 Babeş-Bolyai University, Faculty of Geography, 400006, Cluj-Napoca, Romania e-mail: alina.muresan@ubbcluj.ro
} 
which may become unstable or non-functional due to its critical evolution (Mureşan, 2016). The factors which can cause such processes are considered risk factors, while the territorial unit that is under the influence of said factors may become a critical region. There are a series of regions which, based on the nature of the risk factors acting upon them, can be categorized as such: the Sahel, East and South-East Asia, Amazonia, Aral Lake catchment, the Middle East etc. Sometimes, a geographical unit is not, as a whole, a critical region, despite the fact that it contains several instability factors that generate either natural or man-made geographical risk phenomena. In such cases, one can analyse and emphasize the critical aspects concerning the natural components, the anthropogenic components or both. This is also the case for the region concerned in this paper.

\section{METHODOLOGY}

\subsection{Data}

Methodologically, the paper employs classical methods, such as analysis, synthesis, scientific referencing, field work, as well as more recent methods, such as GIS modelling. Thus, this study contains a first stage, comprising the setting up of a cartographic database through thematic maps and the creation of a statistical database. The second stage includes the instability factor analysis; in order to follow the action of natural factors and the critical aspects generated by them, we performed extensive field research, while the analysis of man-made instability elements, involved the study of the associated risk phenomena and their mapping, based on statistical data.

A major issue in defining critical regions is the set of criteria that stand at the basis of their identification. Assessing the critical aspect of a region is highly subjective due to a lack of precise quantitative and qualitative criteria. One of the elements that may be taken into account is vulnerability, since the higher the vulnerability to geographical risk phenomena, the higher the possibility for defining a territorial entity as critical (Mureșan, 2016). Consequently, after presenting the natural risk phenomena that act at territorial level, we made two maps regarding vulnerability to ravinement and vulnerability to landslides (see point 3.1., fig. 8 and 9), using ranks. In the vulnerability to ravinement map, five factors were taken into account: slope, aspect, lithology, soil texture and land use, followed by a graphical illustration, in order to clearly depict the influence of said factors on ravinement erosion. First we made a thematic map of each factor taken into account, then we reclassified them into four classes 
and transformed vector data into raster data, according to the vulnerability index (very low, low, medium, and high vulnerability). Raster reclassification was based on subjectively attributed scores for each component element of the five factors. Following the processes of thematic map reclassification, transformation into raster system and summing them using the Raster Calculator tool in GIS, we obtained a map of the degree of vulnerability to ravinement.

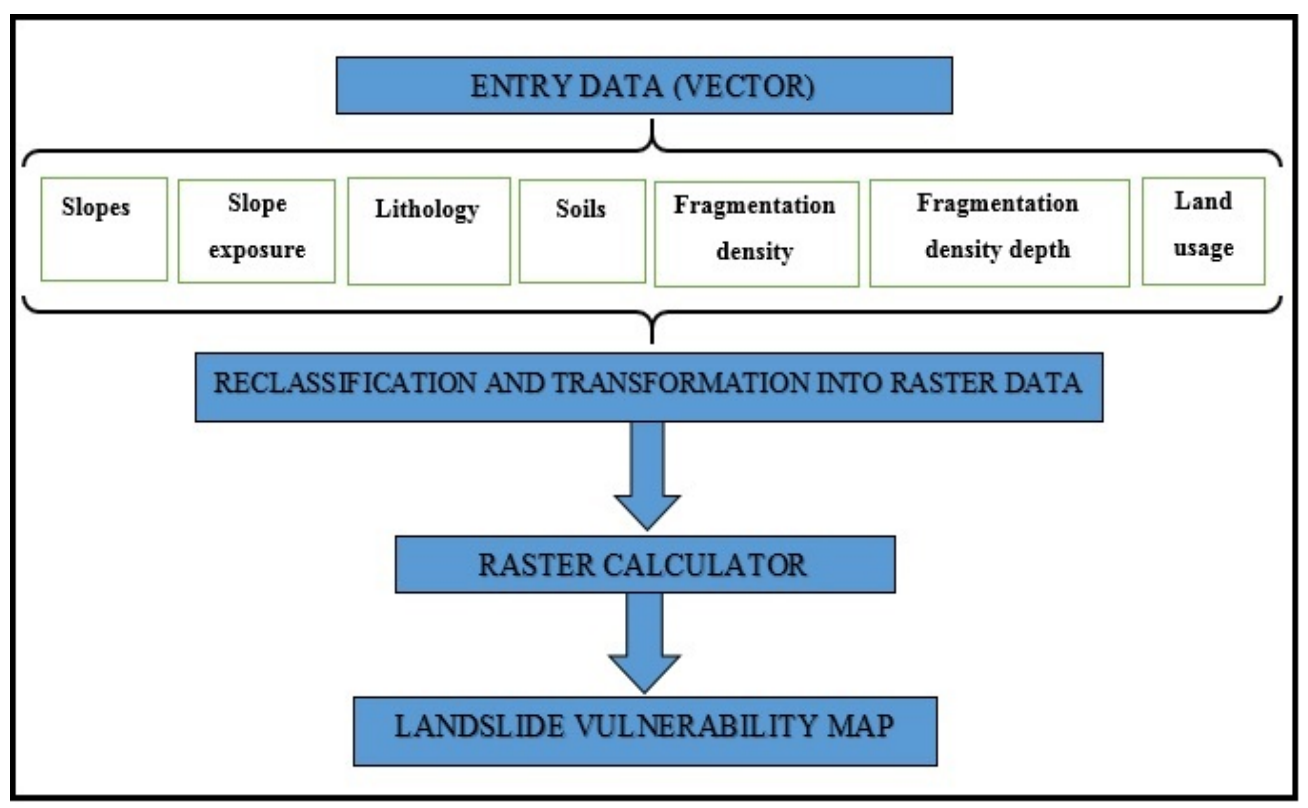

Fig. 1. The methodology used for generating the landslide vulnerability map

In order to generate the landslide vulnerability map, we employed two new factors, apart from the five ones used in generating the ravinement vulnerability map - fragmentation density and fragmentation depth (fig. 1). We also reclassified the seven thematic maps, transforming them into raster data. We then summed them up using GIS (Raster Calculator), the result being the vulnerability to landslides map.

\subsection{Study area}

The study area is part of the larger Baia Mare Basin, covering approximately $600 \mathrm{~km}^{2}$ in Maramureș County. This unit slowly individualized through tectonic, sedimentation and erosion processes from the surrounding areas. To the East, 
the limit to Copalnic Basin is set by Valea Mare - Chechiș watershed, the former valley heading South, while the latter West (Posea, 1962). The south-eastern limit is at the contact with Preluca Range $(810 \mathrm{~m})$, continuing South by means of Bârsău Valley, which also marks the limit to the chrystalline in Dealul MareȚicău $(660 \mathrm{~m})$ near Șomcuta Mare and the exit of Someș River from the gorges upstream Ulmeni and Chelința. To the South-West, Baia Mare Basin reaches Sălaj Hills, continuing West with Codru Range and Piedmont. At around 8-10 meters altitude, one notices the transition from the Someș River floodplain to the piedmont deposits (Geografia României, IV, 1992). In the North-West, the basin makes contact to the low plain of Someș River along Ardusat-Cicârlău alignment, between Codru Range and Gutâi Mountains.

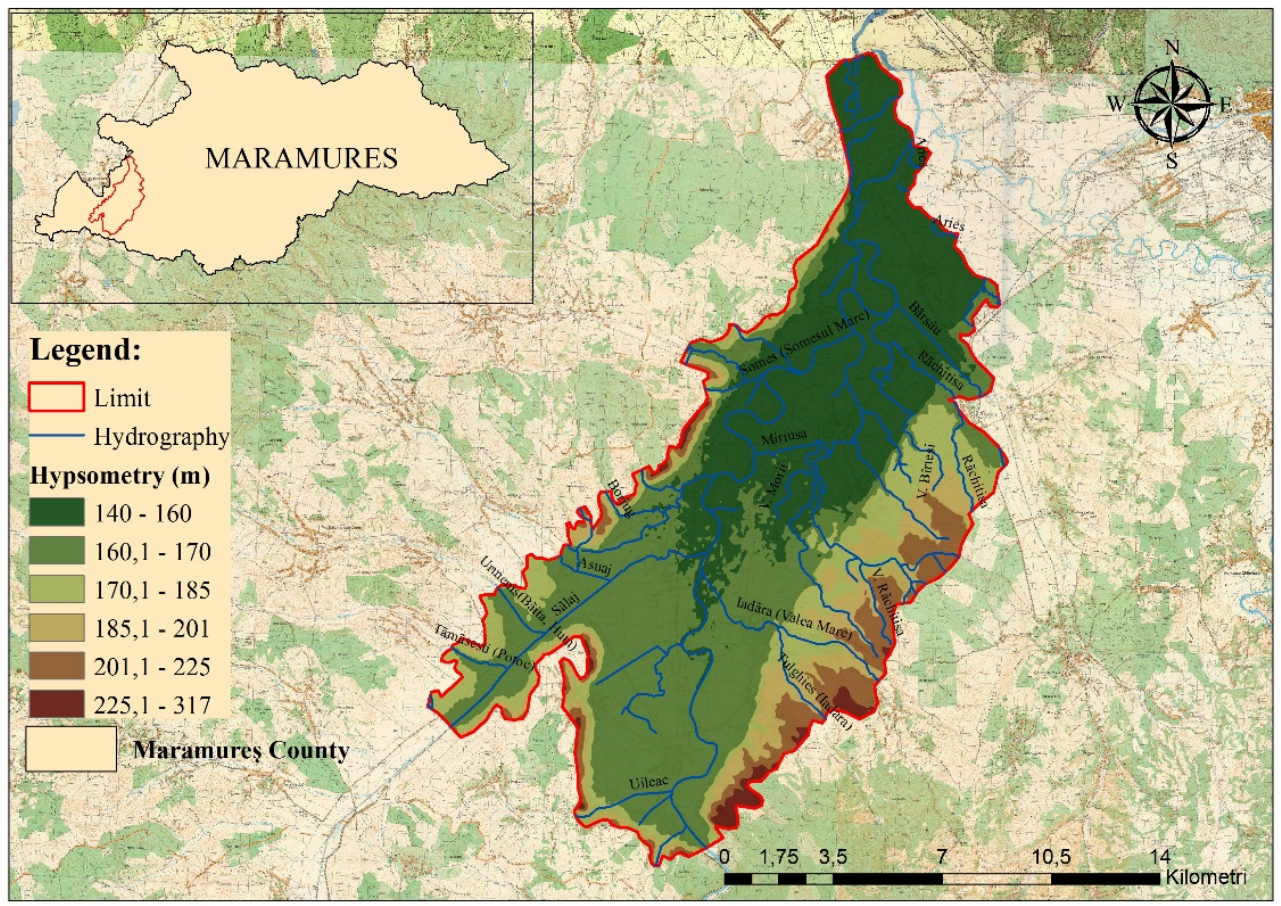

Fig. 2. The location of the study area

The sector chosen to emphasize certain critical aspects is the southwestern part of the basin (fig. 2). Its delineation is based on three elements the soil map, the geological map and the land use map. The criteria for using them were: the presence of cambisoils and clay soils corresponding to their altitudinal levels, the presence of alluvial and gravel deposits as well as sand and clayish 
sandy deposits and, from point of view of land use, the limit between forests and cultivated lands. The minimum altitude is 140 meters corresponding to the northern part of the study area, in the floodplain of Someș River. A major characteristic is the morphological asymmetry, as the highest altitudes are in the south-eastern part of the study area $(317 \mathrm{~m})$. Altitudes slowly descend towards the west and north-west in the hydrographic convergence area marked by the confluence of Someș and Lăpuș rivers. Among the morphometric units, the floodplain of Someș River covers the largest part of the area, as one can clearly notice in the spatial distribution of the heights up to 170 meters.

Administratively speaking, the area includes the town of Ulmeni as well as Ardusat, Satulung, Mireşu Mare, Ariniş, Sălsig, Gârdani and Fărcaşa communes.

\section{CRITICAL ASPECTS. MAJOR INSTABILITY FACTORS}

Among the main instability factors, generating risk phenomena that in turn lead to certain critical aspects, there are natural (mostly geomorphological) factors, as well as anthropogenic factors (related to industrial restructuring and population aging).

\subsection{Natural (geomorphological) factors}

The geomorphological modeling processes that currently occur in the area include landslides, gravity induced mass movement and ravinement processes. The lithology of the area, comprising shale clays, covered by Quaternary deposits made of „contracting and granular clays, placed in a consequent structure” (Măguţ, 2013, p. 74), alongside different human activities such as logging, overgrazing, vegetation removal, soil excavation, building overload, are factors preceding certain geomorphological processes.

In spite of small altitude differences, the landscape is somewhat vulnerable to many geomorphological processes, as there are large areas affected by landslides and ravinement in Chelința, Gârdani, Vicea and Mânău (fig. 3).

The most serious problems are found in Chelința, where an old landslide was reactivated in 2011, damaging 19 houses. Three families had to be relocated in modular homes. The landslide occured from East to West, the same direction as the flow of rain and underground water. This is due to the fact that the riverbed (Hotarului River) is obstructed near road DJ 108E, contributing to the erosion of the enbankment. Most buildings are illegal and made of clay (adobe); thus, no owner has any home insurance, as the community's primary sources of income are welfare grants and child allowances (fig. 4). 

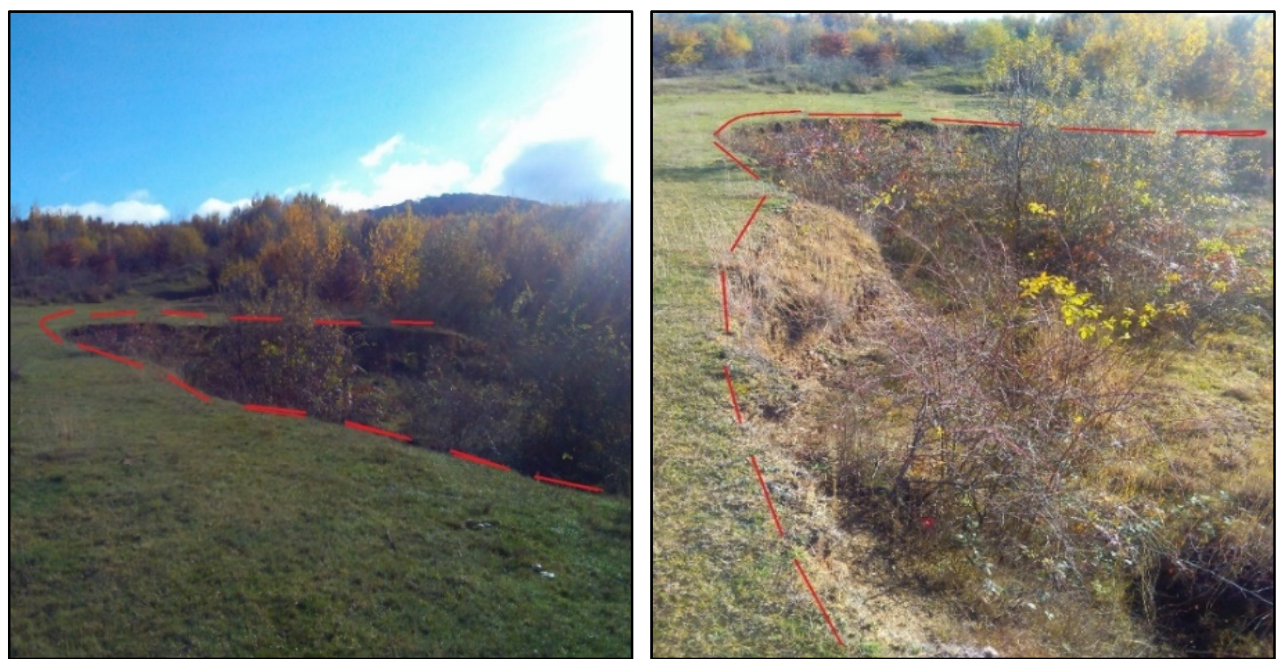

Fig. 3. Landslide in Chelința
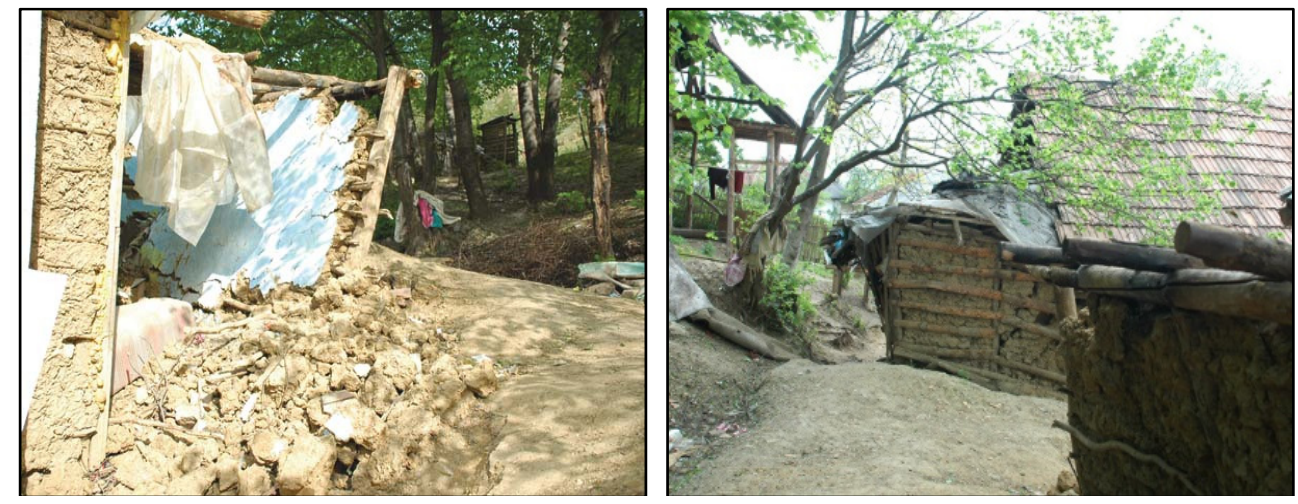

Fig. 4. Adobe houses damaged by the Chelința landslide

Superficial erosion processes occur across the entire study area, but are more prominent in its southern and eastern parts (fig. 5).

Figure 6 depicts the areas most prone to surface erosion, which are areas covered by pastures. Besides the existing type of vegetation, slope declivity and irrational overgrazing are the causes of said process. However, human activities have the highest impact. At Chelința, gullies were formed on dirt roads leading to the nearby forest; due to the large quantities of wood carried each year on these roads, water was able to easily create gullies and ditches (fig. 6). 

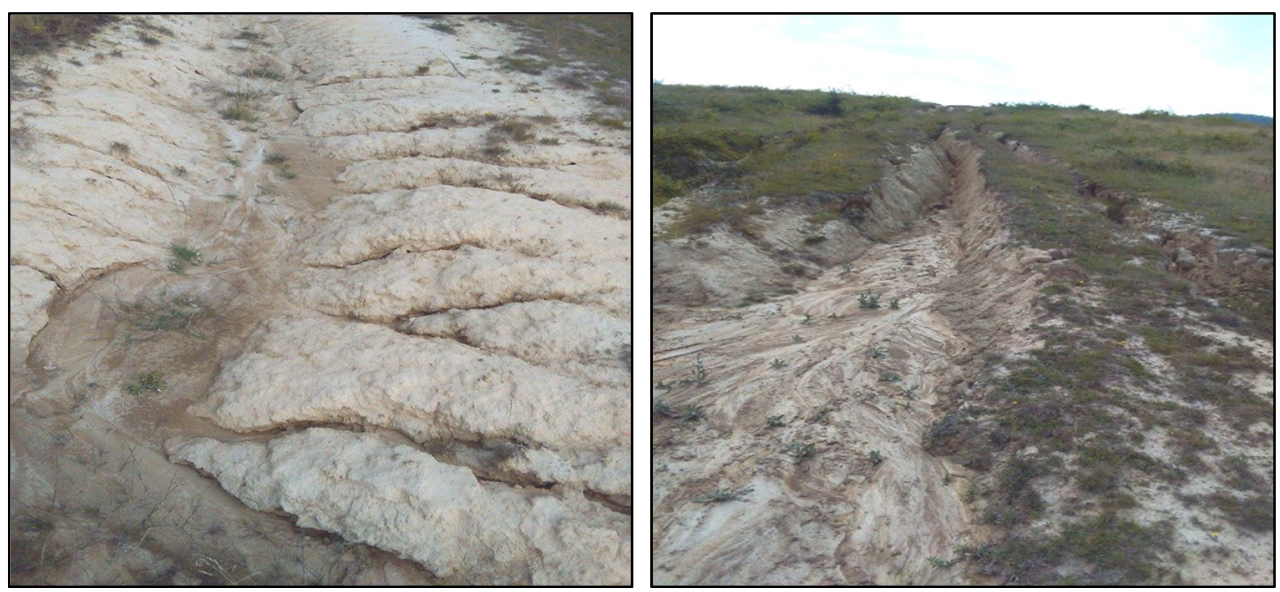

Fig. 5. Gullies
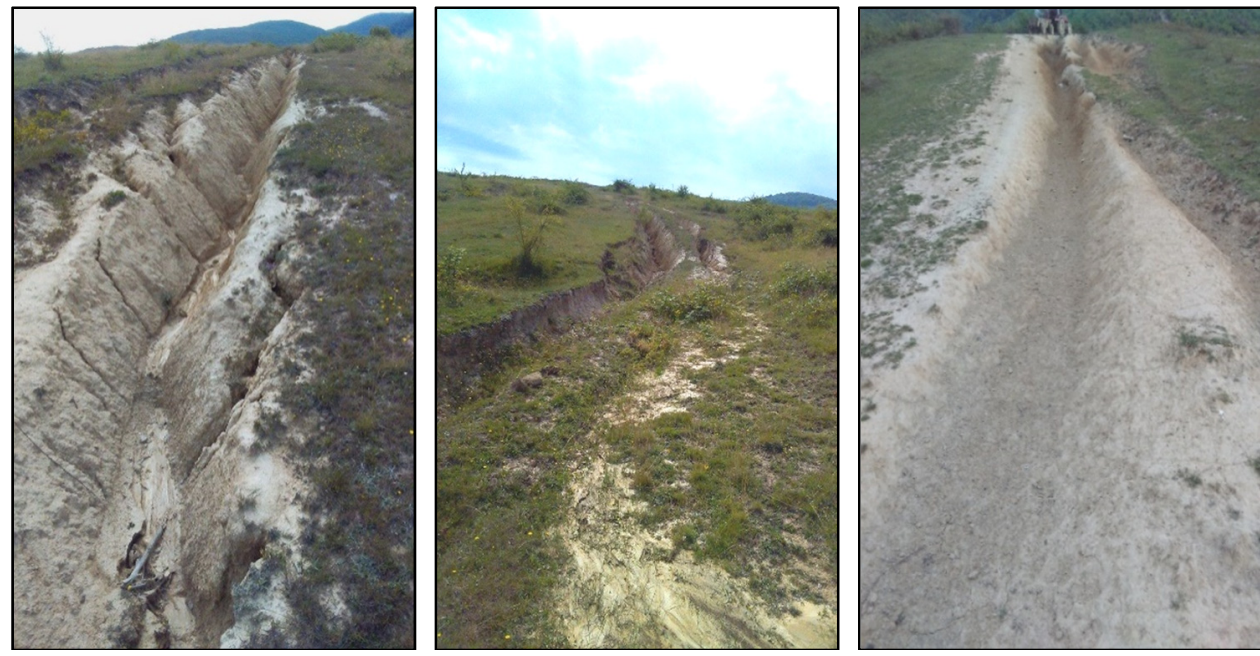

Fig. 6. Former dirt roads leading to the forest, affected by gullies

Linear erosion is the most visible process as the patterns created leave a strong mark on the terrestrial surface. Brittle deposits covering the periphery of the study area led to the appearance of gullies. These deposits are composed of shale, sands, sandstones, Sarmatian conglomerates, clays, and Pannonian sands. Gully erosion is frequent on the outskirts of Chelința and Vicea villages. These gullies are mostly devoid of grass, and their presence in some areas tends to exacerbate erosional processes. Gullies enable the concentrated flow of surface water; this increases their erosional strength, thus leading to deeper and deeper ditches, gullies and eventually ravines. 
Gullies are the main form created by depth erosion, this type of process being facilitated by the sedimentary formations from the hills in the area. Most active gullies can be found in Chelința and Vicea. Their depth varies between 2-5 meters, reaching over 50 meters in length and 2-5 meters in width (fig. 7). The entire slope is scarred by these landforms and are further exacerbated by overgrazing and log transportation.
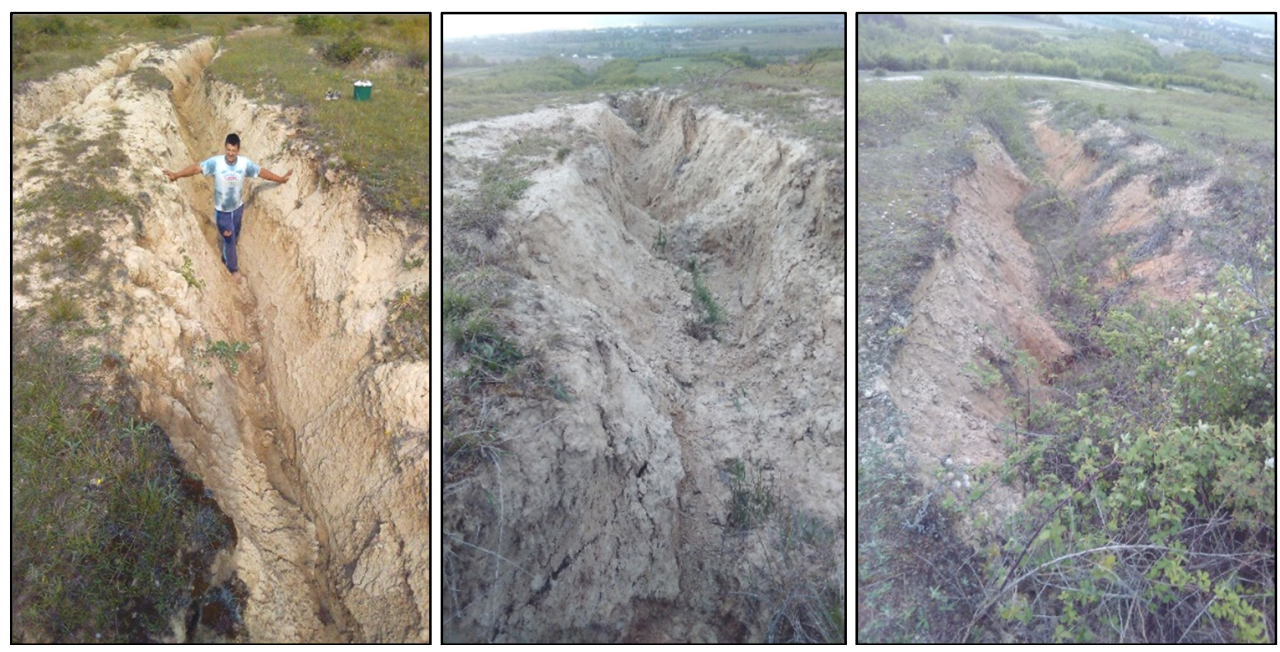

Fig. 7. Gullies in Chelința

Between Vicea and Someș-Uileac, there is a series of gullies reaching 70 meters in length, roughly parallel on the southeastern slope. These landforms are mostly stabilized, but during heavy rains they can reactivate and become torrents. Their evolution is heavily influenced by overgrazing, which strips away the grass cover, allowing water to flow freely.

According to the ravinement vunerability map, the area in question contains four different types of zones (fig. 8):

1. very low vulnerability zones; the vast majority of the area, being located on the banks of the Someș River.

2. low vulnerability zones; the southern and southeastern parts.

3. medium vulnerability zones; in very few areas, overlapping the terrace edges of the Someș River.

4. high vulnerability zones; some parts at the outskirts of Remeți pe Someș, Mânău, Mireșu Mare, Gârdani, Sârbi, and Buzești villages. 


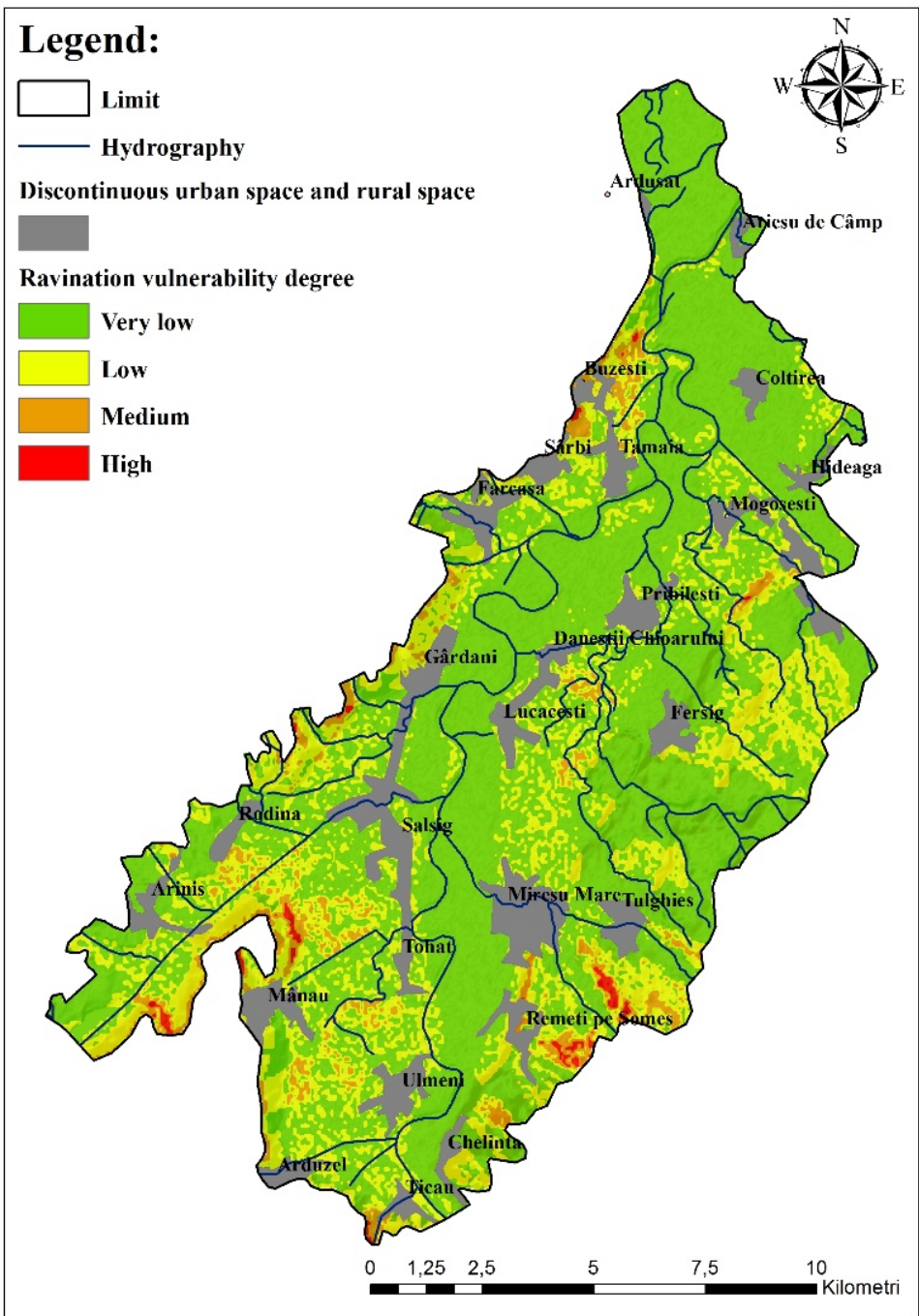

Fig. 8. Map of vulnerability to ravinement

According to the vulnerability map for the south-western part of Baia Mare Basin, there are four vulnerability categories (fig. 9):

1. very low vulnerability areas; roughly $70 \%$ of the analysed territory, comprising the banks of the Somes River and its tributaries in the area.

2. low vulnerability areas; surface areas located on the middle courses of some main valleys. 
3. medium vulnerability areas; lands in the Ariniș, Rodină, Mânău, Chelința, Țicău, and Tulgheș communes.

4. high vulnerability areas; the terraces of the River Someș at Remeți pe Someș, Tulgheș, Chelința, Arduzel, Mânău, Gârdani, Fărcașa, Sârbi and Buzești. The most vulnerable areas are the slopes steeper than 10 degrees, facing northeast, southwest, east and southeast, and with a fragmentation depth of more than $15 \mathrm{~m} / \mathrm{km}^{2}$, surface areas which are largely covered by pastures.

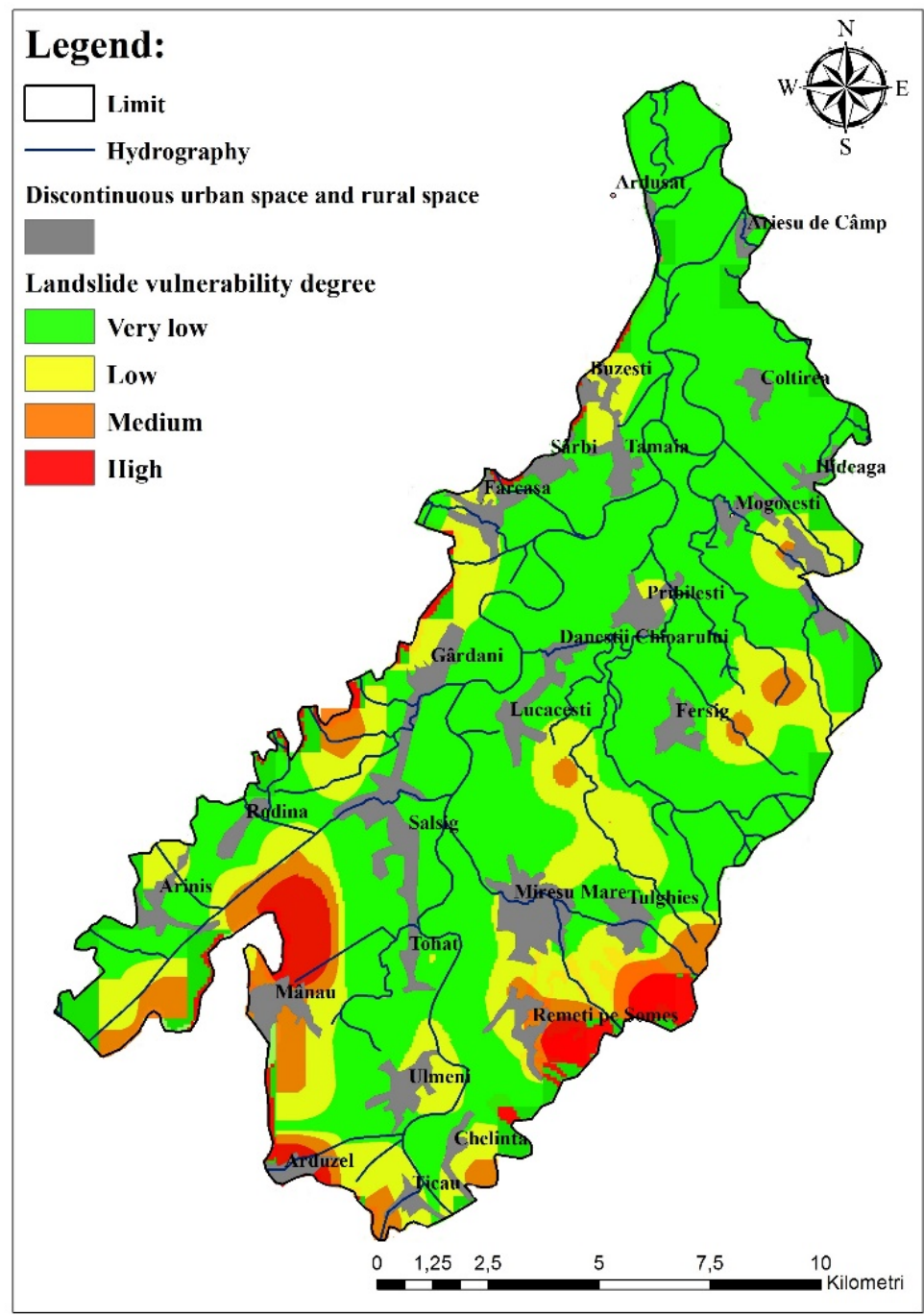

Fig. 9. Map of vulnerability to landslides 


\subsection{The effects of the interaction between natural and anthropo- genic factors on Someş riverbed}

The interaction between the anthropogenic factors and the riverbeds is increasingly noticeable. Very few rivers are untouched by human activities, as their courses are changed, redirected, dammed and overall engineered as well as mined for mineral resources such as gravel, sand etc (Hosu, 2009, Ichim et al., 1989).

On the sector of the Someș River between Țicău and Ardusat there are two phenomena that affect the riverbed. Firstly, there are enbankment works; despite their scarcity, they had major effects on the riverbed. The first sector, between Țicău and Mireșu Mare, has two areas with visible signs of human intervention. On the right bank of the river, near the town of Ulmeni, a series of river improvement works were implemented such as the creation of a sandbag wall which reduces erosion of the river bank (MMP, 2013). Such measures are necessary as, in the spring of 2010, river flow increased dramatically due to torrential rains and snow melting. During the month of April 2010, the village of Chelinţa, part of the town of Ulmeni, was in danger of becoming isolated as flash floods damaged the only access route in the area, that is the road to Ulmeni, and Mireşu Mare (Lazăr, 2016) (fig. 10).
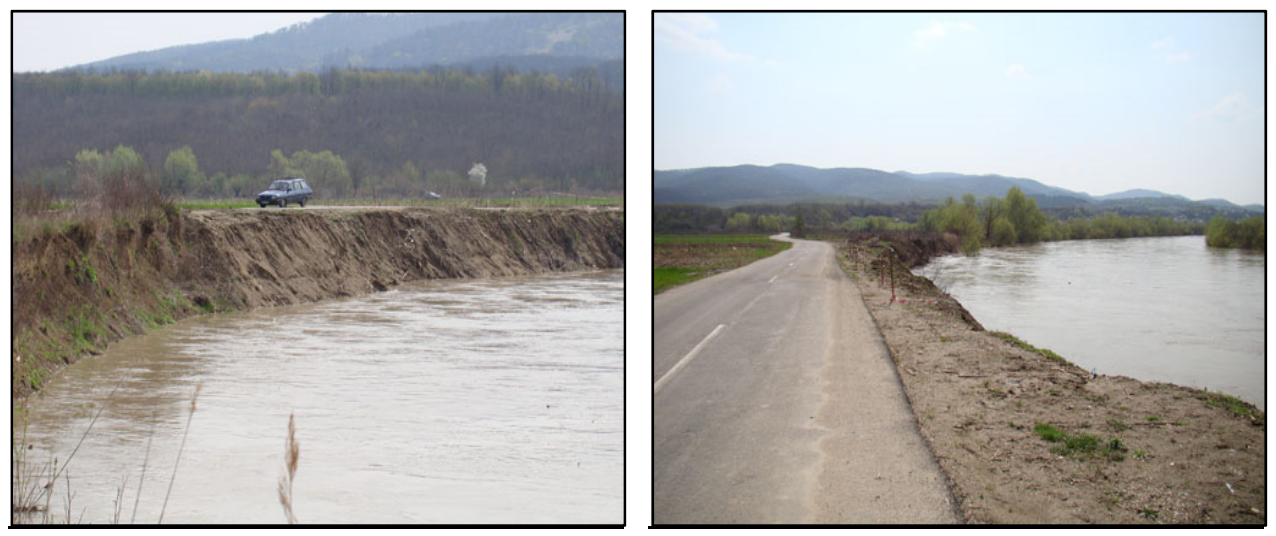

Fig. 10. Shore erosion during the 2010 flood, near Ulmeni Source: http://www.emaramures.ro/stiri/Tipareste-Stire.aspx?NewsID=31899

A similar situation occured roughly 500 meters downstream, on the left bank of the river this time; the bank was stabilized with concrete slabs in order to diminish the side erosion caused by the river (fig. 11) (Lazăr, 2016). 


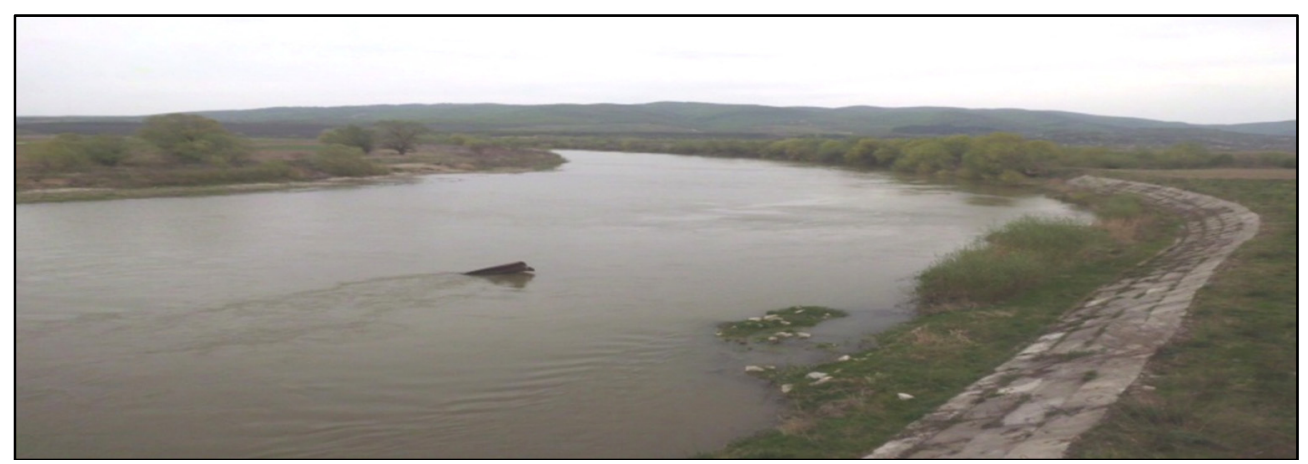

Fig. 11. Stabilization works of the left river bank at Ulmeni

The other situation implies the existence of gravel pits, the most aggressive forms of human intervention. This is due to the fact that the river bed as well as the landforms associated with the river system (banks, floodplains, terraces, alluvial cones) contain massive sand and gravel deposits. Until 2009, Ulmeni had one of the largest gravel pits on the left bank of Someș River. The works were eventually shut down due to poor management. Currently, there are only a handfull of small pits on the outskirts of the town, used solely by the locals (Lazăr, 2016).

In the same sector, between Țicău and Mireșu Mare, there are two gravel pits on the right bank of the Someș River, located in Mireșu Mare. They have a small surface area (less than $1 \mathrm{~km}^{2}$ ), but leave a chaotic and considerable mark on the river bed. The pits are owned by a company specialised in gravel and sand mining, which in turn uses the material for its own concrete producing plant (Lazăr, 2016). Likewise, the pits and their materials are used for the construction and upkeep of local infrastructure, as well as by the communities of Mireșu Mare and its adjacent villages.

The second sector, the one between Mireșu Mare and TămaiaMogoșești suffers from excessive extraction of alluvial deposits. According to the list of planning permits issued in 2013 by the Maramureș County Councils (http://www.cjmaramures.ro/activitate/urbanism/lista-cu-certificatele-deurbanism-si-autorizatiile-de-construire-desfiintare-emise), there are three such pits in development, located on the right bank of Someș River, two in Lucăcești and one in Dăneștii Chioarului, located less than $2 \mathrm{~km}$ from each other. Dăneștii Chioarului pit sits on a richer deposit, as it is located on a slip-off slope (fig. 12). Downstream, near Pribilești, there is another functioning gravel pit (Lazăr, 2016). 


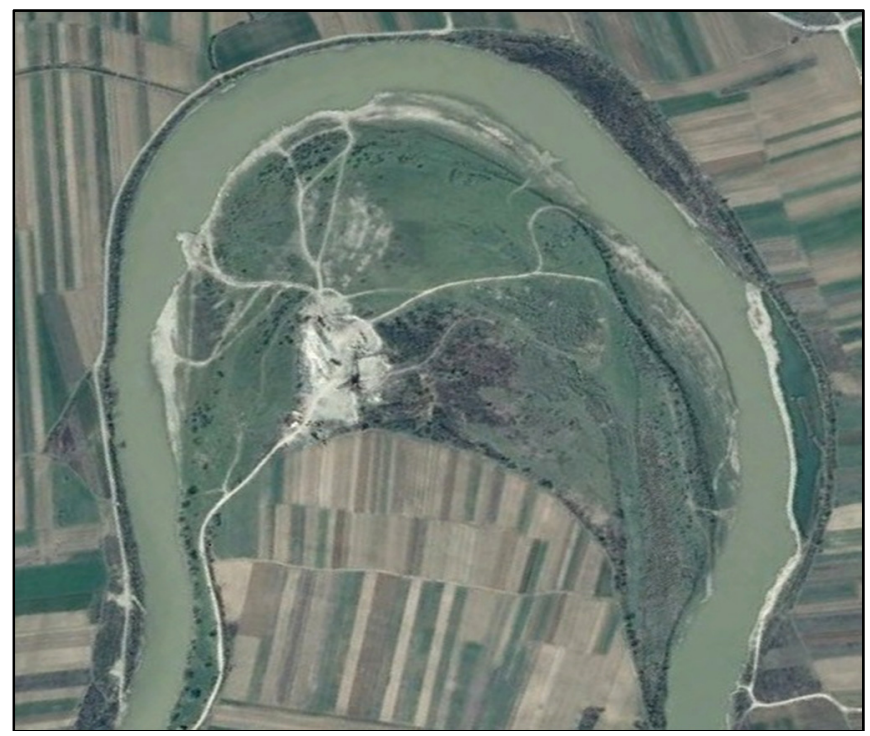

Fig. 12. Slip-off slope and sand point bar on the right bank of the Someș River, near Pribilești

Source: Google Earth

The left bank has a similar situation, as Fărcașa hosts a concrete plant which uses sand from a pit located downstream. The company running these two locations also administers the gravel pits of Pribilești, Mogoșești and Sîrbi. This sector, due to the environmental impact of man-made structures and human intervention, is heavily destabilized, and contains areas affected by artificial deepening which, in time, may undermine the banks and the slopes. As the alluvial deposits located along Someș River are suitable for constructions, a few extraction points emerged chaotically in several locations. The same situation can be found downstream of Tămaia, on the left side of the river, where, all the way to Ardusat, there are four more gravel pits and one asphalt production facility. The extraction is done by excavators. For an efortless extraction from the riverbed, several dirt roads were built, some of them right next to the river (fig. 13) (Lazăr, 2016).

Generally speaking, there is a large concentration of gravel and sand pits on the right bank of the Someș River. This can be easily explained by the tendency of the river to move to the right, while the flood plain decreases and the neighbouring agricultural fields lose their importance.

The landforms generated by these pits are extremely varied; the most visible are the existing excavations in active as well as in abandoned pits (Lazăr, 2016). 


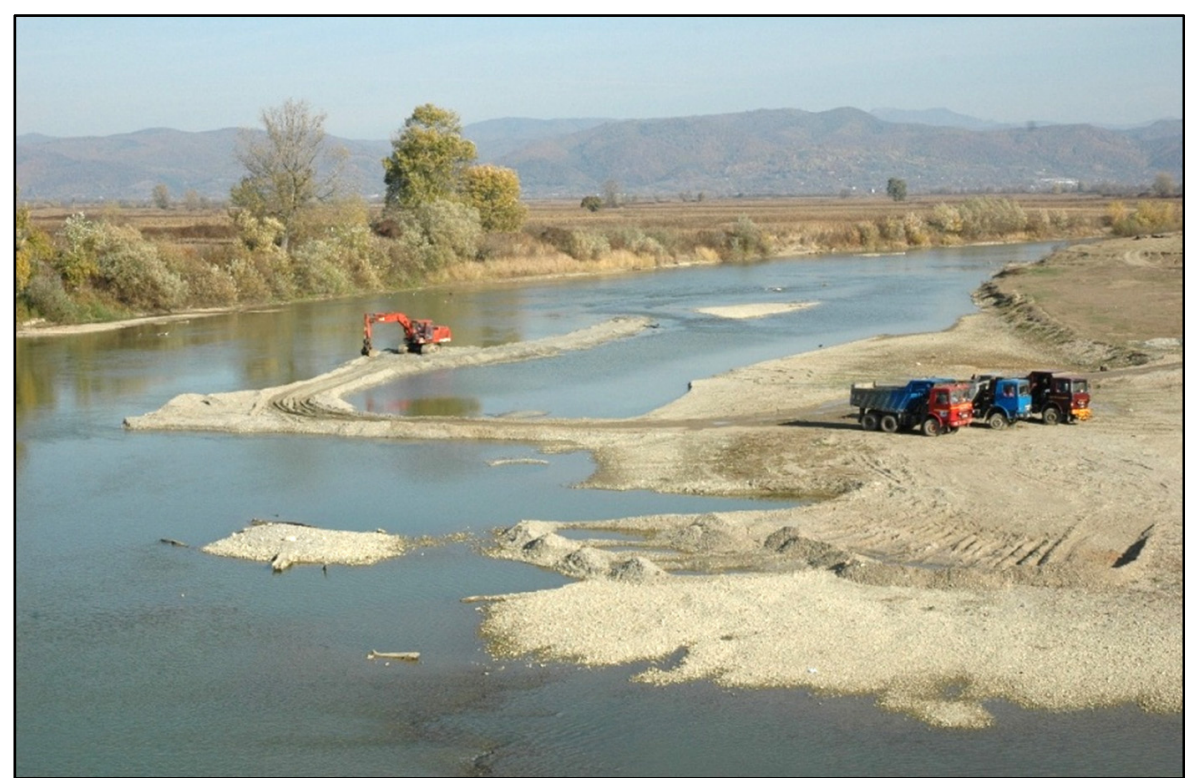

Fig. 13. Alluvial deposits extraction by artificial headlands

Source: http://www.infomm.ro/

http://www.ziare.com/Baia Mare/stiri-business/grav-raurile-din-maramuresexploatate-salbatic-160-000-mc-de-balast-se-extrag-anualdin-raurile-din-judet-5374825

\subsection{Anthropogenic factors}

Among the human-related factors that can be found at regional level and trigger certain critical aspects, we chose to present industrial restructuring and population aging.

Most industrial units in the area are currently privately owned and their activity decreased considerably, some to the point of closure. Some industrial areas and buildings were rented to small businesses active in production and industrial services, storage, in precarious conditions, while the remaining spaces are left idle and in a high degree of degradation. In most communes, there are a handful of companies with insufficient jobs for the entire active population; many are involved in logging, mineral extraction (sand for instance from riverbeds) and transportation. The most significant problems in this sector are the inefficient capitalization of agricultural products, large scale commuting towards the city of Baia Mare and lack of investment. 
The degree of population aging was represented by calculating the population aging index for all eight administrative-territorial units for a period of 10 years (2006-2016). The report date was the $1^{\text {st }}$ of July each year. According to the graph below, one can notice that all administrative-territorial units have a higher index than the 0.42 threshold value (fig. 14). Thus, the demographic aging phenomenon is quite severe.

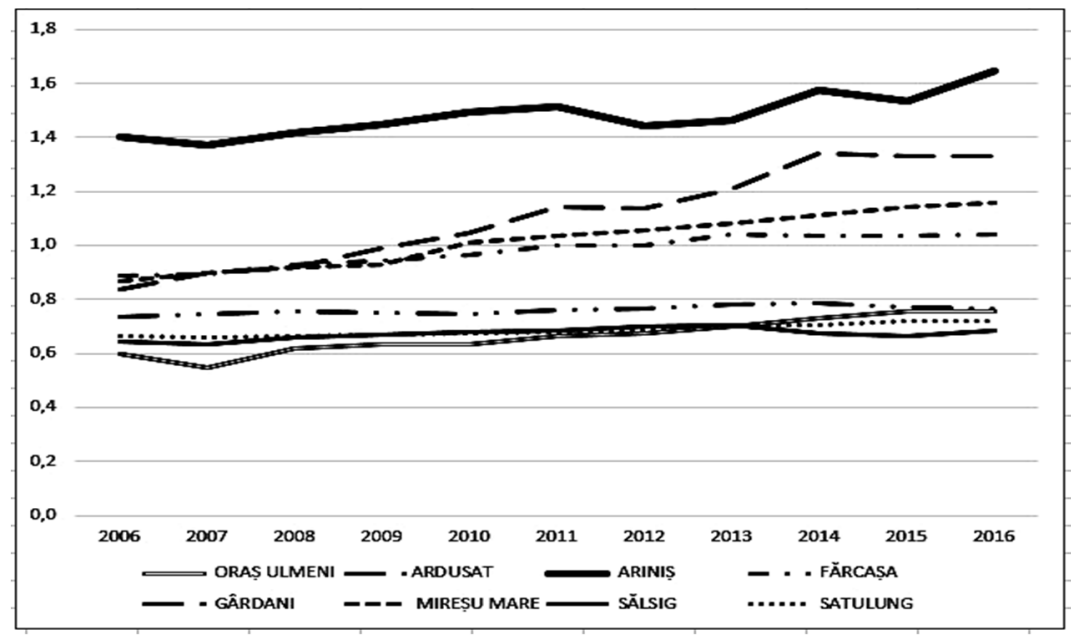

Fig. 14. The demographic aging index

The commune with the highest index is Ariniș; between 2006 and 2016 , its index increased, reaching the value of 1.6 on the $1^{\text {st }}$ of July 2016 . This commune is followed by Gârdani, which experienced considerable growth until 2014, when it reached 1.3. In the following two years however, its index decreased. The lowest value was registered in Ulmeni, with a value below 1, but its index has been continually rising since 2007 .

\section{CONCLUSIONS}

This paper focuses on analysing the main natural and human instability factors, found in the south-western part of Baia Mare Basin.

The main critical aspects emphasized concern both the presence and manifestation of natural (mostly geomorphological) factors, as well as anthropogenic factors. These critical aspects are due, first of all, to the existence of landslides and ravines on large areas, as these pose a serious threat to the population. Also crucial is the interaction between the geomorphological and anthropogenic factors, that manifests itself in the river bed of Someș as gravel pits. Finally, several critical aspects induced by anthropogenic factors have been emphasized, the most relevant concerning industrial decline and demographic aging for the entire area. 


\section{R E F E R E N C E S}

1. Arghiuș, Corina, Surdeanu, V. (2004), Morfodinamica albiei Someșului între Ulmeni şi Ardusat (1981-1996), Lucrările Simpozionului „Geografia în contextual dezvoltării contemporane", 12-14 septembrie 2003, Cluj-Napoca.

2. Boțan, C. N. (2005), Aspecte critice în sistemul geografic al Ţării Moților, în Studia Universitatis Babeş-Bolyai, Geographia, nr. 2, p. 81-92.

3. Cocean, P. (coord.) (2004), Planul de amenajare a teritoriului Regiunii de NordVest (PATR), Editura Presa Universitară Clujeană, Cluj-Napoca

4. Goțiu, Dana, Surdeanu, V. (2008), Hazardele naturale și riscurile asociate din Tara Hațegului, Presa Universitară Clujeană, Cluj-Napoca.

5. Hosu Maria (2009), Valea Someşului între Dej şi Țicău. Studiu geomorfologic, Presa Universitară Clujeană, Cluj-Napoca.

6. Ichim, I., Rădoane, Maria, Bătucă, D., Duma, D. (1989), Morfologia şi dinamica albiilor de râuri, Edit. Tehnică, București.

7. Lazar Aurelia-Daniela (2016), Impactul factorului antropic asupra albiei Someșului. Studiu de caz: Sectorul Ţicău-Ardusat, în Tendințe actuale în predarea şi învăţarea geografiei, vol. 15, 2016, pp. 23-33.

8. Marian, R. A., (2013), Studiu geoinformatic privind impactul hidric al avariilor rețelelor de alimentare cu apă din mediul rural. Aplicație la Depresiunea Baia Mare, Teză de doctorat, Cluj-Napoca.

9. Măguț, Flavia Luana (2013), Riscul la alunecări de teren în Depresiunea Baia Mare, Teză de doctorat, Cluj-Napoca.

10. Ministerul Mediului şi al Pădurilor, Plan de apărare împotriva inundaţiilor şi ghețurilor, secetei hidrologice, accidentelor la construcțiile hidrotehnice şi poluărilor accidentale al bazinului hidrografic Someş-Tisa, memoriu tehnic, http://www.rowater.ro/dasomes/planbaz/plan\%20bazinal\%2020102013.htm, accesat în 2016.

11. Mureșan, Gabriela-Alina (2016), Regiuni critice, Editura Risoprint, Cluj-Napoca.

12. Popa, R., (1997), Elemente de hidrodinamica râurilor, Editura Didactică și Pedagogică, București.

13. Posea, G. (1962), Țara Lăpuşului: studiu geomorfologic, Edit. Ştiinţifică, Bucureşti.

14. *** (2015), „GRAV-Râurile din Maramureş, exploatate sălbatic. 160.000 mc de balast se extrag anual din râurile din județ, Baia Mare",

http://www.ziare.com/Baia Mare/stiri-business/grav-raurile-din-

maramures-exploatate-salbatic-160-000-mc-de-balast-se-extrag-anual-dinraurile-din-judet-5374825, accesat în 2016.

15. *** (1992), Geografia României. Vol. IV. Regiunile pericarpatice: Dealurile şi Câmpia Banatului și Crişanei, Podiş̧ul Mehedinți, Subcarpații, Piemontul Getic, Podişul Moldovei, Edit. Academiei Române.

16. http://www.cjmaramures.ro/activitate/urbanism/lista-cu-certificatele-deurbanism-si-autorizatiile-de-construire-desfiintare-emise. 